\title{
LANGKAH PENCEGAHAN KONFLIK BERSENJATA
}

\author{
Mahfud \\ Faculty of Law University of Syiah Kuala \\ Email: mahfud.abdullah@yahoo.co.id
}

\begin{abstract}
Completion of the armed conflict in both the legal and political framework set in customary international law and the Hague Convention I of 1899 and 1907 on the peaceful resolution of disputes, as well as the Charter of the United Nations. Mechanisms for resolving armed conflicts as well as measures to prevent the emergence of armed conflict refers to the two methods of dispute resolution, the peaceful resolution of disputes and the settlement of disputes by force or violence. Patterns in the context of conflict resolution approach more focused on the efforts of early stage to prevent the emergence of armed-conflict. Such efforts can be done with diplomacy and political mediation efforts by involving the various parties that are considered to be actors of peace. While humanitarian law in the context of normative law enforcement efforts imprinted on the situation of the ongoing war, one of its forms through foreign intervention in the ongoing armed conflict itself. In the present context of the humanitarian intervention of humanitarian law known as the Responsibility to Protect $(R$ to $P)$. In addition through the UN mechanism for the continuous efforts of the international community to prevent the emergence of armed conflict also involving a number of other actors who can be considered a partner for peace. One of them involving specific groups that can be considered a party to break the chain of armed conflict itself. One of them is through the mechanism of the Kimberley Process.
\end{abstract}

Key words: arm conflict, resolution, United Nations

\begin{abstract}
ABSTRAK
Penyelesaian konflik bersenjata dalam kerangka hukum dan politik yang diatur dalam hukum kebiasaan internasional dan Konvensi Den Haag I tahun 1899 dan 1907 tentang penyelesaian konflik secara damai, serta Piagam Perserikatan Bangsa-Bangsa. Mekanisme untuk menyelesaikan konflik bersenjata serta langkah-langkah untuk mencegah munculnya konflik bersenjata mengacu pada dua metode penyelesaian sengketa, penyelesaian damai sengketa dan penyelesaian sengketa dengan kekerasan atau kekerasan. Pola dalam konteks pendekatan resolusi konflik lebih fokus pada upaya tahap awal untuk mencegah munculnya konflik bersenjata. Upaya tersebut dapat dilakukan dengan upaya diplomasi dan mediasi politik dengan melibatkan berbagai pihak yang dianggap sebagai pelaku perdamaian. Sementara hukum humaniter dalam konteks upaya penegakan hukum normatif tercetak pada situasi perang yang sedang berlangsung, salah satu bentuknya melalui intervensi asing dalam konflik bersenjata yang sedang berlangsung itu sendiri. Dalam konteks sekarang intervensi kemanusiaan dari hukum humaniter dikenal sebagai Responsibility to Protect ( $R$ to $P$ ). Selain itu melalui mekanisme PBB untuk upaya berkelanjutan dari komunitas internasional untuk mencegah munculnya konflik bersenjata juga melibatkan sejumlah aktor lain yang dapat
\end{abstract}


dianggap sebagai mitra perdamaian. Salah satunya melibatkan kelompok-kelompok tertentu yang bisa dianggap sebagai pihak untuk memutus rantai konflik bersenjata itu sendiri. Salah satunya adalah melalui mekanisme Proses Kimberley.

\section{Kata kunci: konflik senjata, resolusi, PBB}

\section{Pendahuluan}

Sebagai bagian dari sirklus sosial perang telah dianggap sebagai ritual survival dari kelompok sosial. Rentatan sejarah bertahan hidup kelompok sosial yang dipenuhi pergulatan kekerasan berupa perang, telah menjadikan manusia menjadi korban utama dari kebijakan yang dibuatnya sendiri. Perang demi perang dengan evolusi senjata yang dipakai para pihak yang terlibat dalam suatu peperanggan semakin memperkukuh pentingnya memperdulikan nilai kemanusiaan yang muncul akibat perang. Perang pula yang kemudian memulai dan menutup petempuran, termasuk mencegah munculnya konflik bersenjata baru. ${ }^{1)}$

Sejarah mencatat bahwa sulit menemukan suatu negara yang tidak pernah terlibat dalam perang karena perang itu merupakan tingkah laku sosial yang muncul pada hampir semua bangsa dalam mencapai tujuan-tujuan geopolitiknya, dan lebih jauh lagi bahwa perang sesungguhnya suatu bentuk tingkah laku yang hanya dapat ditemukan di dalam lingkungan manusia

1) Edisi Koleksi Angkasa, Pistol, Rifles, and Machine Gun, April 2006, hlm 3-4. yang mengenal kehidupan bernegara. ${ }^{2)}$ Oleh karenanya, pelaksanaan perang itu sendiri disesuaikan dengan serangkaian formalitas atau peraturan sebagai bagian dari sistem hukum tertentu, atau perang ditujukan demi alasan-alasan yang dapat dipertanggungjawabkan menurut kaidah agama atau adat istiadat masyarakat tertentu. ${ }^{3)}$ Faham-faham tentang perang ini sendiri dapat dilihat dari dua kutub pandangan ekstrem, yaitu golongan "militiarists" (cinta perang) dan kedua, golongan pacifists (cinta damai), yang menurut Austin Fagathey keduanya tak dapat bertemu. Austin mengatakan bahwa :

“...militarists look on war as inavitable, as a natural expression of man's anggressive instincts, as a necessary element in a nation's growth and as the normal means by which it play its role in history. Pasifists think that violence and bloodshed, whatever tendencies man may have to ward indulging his fighting insticts, are so wrong in themselves that to use them even for

2) E. Koswara, Agresi Manusia, PT Eresco, Bandung, 1988, hlm 151.

3) Majid Khadduri, War and Peace in The Law of Islam (Perang dan Damai dalam Hukum Islam), Tarawang Press, Jakarta, 2002, hlm 47. 
defense is to use an evil means for good end..." 4)

Manusia sebagai mahluk bermasyarakat yang hidup dalam suatu masyarakat besar dan negara akan menghadapi berbagai tantangan dan salah satu cara untuk mempertahankan diri dari tantangan tersebut adalah melalui berperang. Hal ini sebagaimana digambarkan oleh Aristoteles yang menyatakan bahwa :

"...war in itself is a physical evil, it becomes a moral evil only when there is injustice on the part of one using the force..." 5)

Karena itu seterusnya Austin Fagathey mengembangkan lebih lanjut teori perang yang benar dan adil atas dasar tiga syarat :

1. Pimpinan yang sah, artinya militer dapat digerakkan untuk berperang bila diperintah oleh pejabat yang berwenang.

2. Ada alasan atau dasar yang kuat sehingga merupakan langkah terakhir dan terpaksa, setelah segala bentuk dan upaya gagal.

3. Cita-cita yang benar atau luhur, sehingga meratakan tindakan yang adil dan tidak bertentangan dengan hati nurani. ${ }^{6}$ )

Oleh karena itu di butuhkan suatu aturan hukum, yaitu "Hukum Perang" yang terdiri dari sekumpulan pembatasan

\footnotetext{
4) H.A. Masyur Effendi, Hukum Humaniter Internasional dan Pokok-Pokok HANKAMRATA, Usaha Nasional, Surabaya, 1994, hlm 20.

5) ibid.

6) ibid.
}

oleh hukum internasional dalam mana kekuatan yang diperlukan untuk mengalahkan musuh boleh digunakan dan prinsip-prinsip yang mengatur perlakuan terhadap individu-individu pada saat berlangsungnya konflik-konflik bersenjata. ${ }^{7)}$ Karena pada umumnya dalam suatu konflik atau sengketa yang demikian nilainilai kemanusiaan sering terabaikan. ${ }^{8)}$

Tujuan pokok dari kaidah-kaidah hukum ini untuk alasan-alasan prikemanusiaan guna mengurangi atau membatasi penderitaan individu-individu, serta untuk membatasi kawasan di dalam mana kebiasaan konflik bersenjata diizinkan. Karena alasan inilah, ketentuanketentuan itu kadang-kadang disebut sebagai "Hukum Perang Humaniter" atau kaidah-kaidah hukum "Perang Yang Berperikemanusiaan". Nama-nama yang pada saat ini diakui untuk kaidah-kaidah tersebut adalah "Hukum Humaniter Internasional".

Naluri berperang ini kemudian membawa keinsyafan bahwa cara berperang yang tidak mengenal batas itu merugikan umat manusia sehingga kemudian mulailah orang-orang mengadakan pembatasanpembatasan, menetapkan ketentuan-

7) T. May Rudy, Hukum Internasional 2, Refika Aditama, Bandung, 2001, hlm 78.

8) Lachs, Manfred, Responsibility For The Development of Humanitarian Law, and Cristopher Swinarski (Ed), Studies and Essay on International Humanitarian Law and Red Cross Principles, Martinus Nijhoff Publishers, Laiden, 1984, hlm 397. 
ketentuan yang mengatur perang antara bangsa-bangsa. Pelanggaran-pelanggaran tersebut, dapat berupa pelanggaran dalam bentuk international crimes atau international torts (international delinquencies). ${ }^{9)}$ Di dalam bentuknya yang modern sebagai suatu asas dasar dari hukum perang, maka asas prikemanusiaan ini untuk pertama kali dirumuskan dengan tegas oleh J.J. Rouseau yang menyatakan dalam "Contract social" :

"war then is a relation, not between man and man but between State and State and individuals are enemies only accidentally, not as men, nor even citizen as but as soldiers, not as members of their country but as its defenders...

the object of war being the destruction of the hostile State, the other side has right to kill its defenders, while there are bearing arms; but as soon as they lay them down and surrender, they cause to be enemies or instruments of the enemy, and become once more merely men, whose life no one has any right to take". ${ }^{10)}$

Oleh karena itu ICRC (International Committee of The Red Cross) yang didirikan kurang dari 150 tahun yang lalu berupaya untuk mewujudkan suatu pembatasan dari suatu perperangan itu sendiri, dengan suatu

9) Romli Atmasasmita, Pengantar Hukum Pidana Internasional, Refika Aditama, Bandung, 2000, hlm 11.

10) Mochtar Kusumaatmadja, Konvensi-Konvensi Palang Merah 1949, PT Alumni, Bandung, 2002. hlm 11. prinsip bahwa dalam perang pun ada batasanbatasannya. Batasan tentang bagaimana seharusnya perang itu dilakukan, dan batasan seharusnya bagaimana para kombatan itu berperilaku. Seperangkat aturan yang dibentuk berdasarkan prinsip-prinsip tersebut dan disahkan oleh negara-negara di dunia dikenal sebagai Hukum Humaniter Internasional (HHI) di mana konvensi Jenewa merupakan landasan hukum utamanya. $^{11)}$

Istilah hukum humaniter atau lengkapnya disebut international humanitarian law applicable in armed conflict berawal dari istilah hukum perang (laws of war), yang kemudian berkembang menjadi hukum sengketa bersenjata (laws of armed conflict), yang akhirnya pada saat ini biasa dikenal dengan istilah hukum humaniter. Mengenai perubahan penggunaan istilah hukum ini menjadi Hukum Sengketa Bersenjata (Laws of Armed Conflict) Edward Kossoy menyatakan :

"The term of armed conflict tends to replace at least in all relevan legal formulation, the older notion of war. On purely legal consideration the replacement for war by 'armed conflict' seems more justified and logical", 12)

Istilah hukum sengketa bersenjata (law of armed conflict) sebagai pengganti hukum perang (law of war) banyak dipakai dalam

11) Buletin ICRC, ICRC Dalam Kilasan, Maret 2001, hlm 2 .

12) Arlina Permana Sari dkk, Pengantar Hukum Humaniter, ICRC, Jakarta, 1999, hlm 7. 
Konvensi-Konvensi Jenewa 1949 dan kedua Protokol Tambahannya. Dalam perkembangan selanjutnya, yaitu pada permulaan abad ke-20, diusahakan untuk mengatur cara berperang, yang konsepsikonsepsinya banyak dipengaruhi oleh asas kemanusiaan (humanity principle).

Dengan adanya perkembangan baru ini, maka istilah hukum sengketa bersenjata mengalami perubahan lagi, yaitu diganti dengan istilah Hukum Humaniter Internasional, yang berlaku dalam Sengketa Bersenjata (International Humanitarian Law Applicable in Armed Conflict) atau biasa disebut Hukum Humaniter Internasional (International Humanitarian Law). Walaupun istilah yang digunakan berbeda-beda, yaitu Hukum Perang, Hukum Sengketa bersenjata dan Hukum Humaniter, namun istilah-istilah tersebut memiliki arti yang sama. ${ }^{13)}$

Hukum Humaniter Internasional membentuk sebagian besar hukum publik internasional dan terdiri dari peraturanperaturan yang pada masa konflik bersenjata, berusaha melindunggi orang-orang yang tidak atau tidak dapat lagi terlibat dalam permusuhan, dan untuk membatasi alat dan cara berperang yang digunakan. Untuk alasan-alasan kemanusiaan peraturanperaturan tersebut membatasi hak pihakpihak yang terlibat dalam konflik dalam hal

\footnotetext{
13) ibid, hlm 8
}

pemilihan alat dan cara berperang, serta memberikan perlindungan kepada orangorang dan hak milik yang terkena dampak atau kemungkinan besar akan terkena dampak dari konflik. ${ }^{14)}$

Merupakan suatu ketentuan bahwa para pihak yang terlibat dalam suatu konflik bersenjata mempunyai hak untuk mengunakan senjata tidak tak terbatas untuk tujuan dan maksud dari peperangan. Pembatasan ini didasarkan pada dua ketentuan. Pertama, ketentuan tentang prinsip-prinsip umum mengenai persenjataan yang sudah dikembangkan. Kedua, masyarakat internasional yang sudah menerima sejumlah larangan khusus atau setiap pembatasan di mana telah disepakati suatu bentuk tertentu dari persenjataan atau metode peperangan. ${ }^{15)}$

Sebagaimana ketentuan Pasal 35 Protokol tambahan I tahun 1977 mengakui bahwa maksud dari melukai musuh dengan tidak tak terbatas ini, dan kemudian menetapkan larangan bagi para personil militer mengunakan materi dan peluru atau metode perang yang secara nyata menyebabkan luka yang berlebihan atau penderitaan yang tidak perlu. Ini sebagaimana diatur dalam perjanjian atau ketentuan lain yang merupakan

14) Buletin ICRC, Hukum Humaniter Internasional (Menjawab Pertanyaan-pertanyaan Anda), Febuari 2004, hlm 4.

15) Evans, Malcom D, International Law, Published in The United State by Oxford University Press Inc, New York, 2003, hlm 802. 
penghormatan terhadap kebiasaan dari hukum perang itu sendiri, seperti Deklarasi St Petersburg tahun 1869, Deklarasi Deng Haag I tahun 1899 tentang larangan pengunaan gas pencekik dan Deklarasi Deng Haag II tentang peluru dum-dum serta Konvensi Deng Haag IV tahun 1899 beserta Annex tentang pengaturan mengenai hukum dan kebiasaan perang di darat. ${ }^{16)}$

\section{Analisis dan Pembahasan}

PBB sebagai wadah organisasi dunia mengatur secara seksama pola penyelesaian sengketa internasional termasuk penyelesaian konflik bersenjata maupun mencegah munculnya konflik bersenjata. Dengan tujuan agar sengketa tersebut dapat diselesaikan sedini mungkin dan dengan cara yang jujur dan adil. Upaya penyelesaian konflik bersenjata baik dalam kerangka hukum dan politik diatur dalam hukum kebiasaan internasional maupun Konvensi Den Haag I tahun 1899 dan 1907 tentang penyelesaian sengketa secara damai, serta Piagam Perserikatan Bangsa-bangsa. Piagam ini menetapkan pembentukan organisasi internasional yang dimaksudkan untuk mempermudah

16) Aust, Anthony, Handbook of International Law, Published in The United State by Cambrige University Press, New York, 2005, hlm 255. penyelesaian sengketa antar negara secara damai. ${ }^{17)}$

Sebagai bagian dari upaya politik, persoalan tentang penyelesaian sengketa baik upaya untuk menghindarkan munculnya konflik bersenjata. Komunitas internasional berusaha untuk mencegah baik munculnya konflik maupun meredam aksi konflik yang sedang berlangsung untuk tidak melenceng dari prinsip norma hukum perang. Dalam kontek politik dan hukum mekanisme penyelesaian konflik maupun upaya meredam muncuknya konflik bersenjata mengacu pada dua macam cara penyelesaian sengketa, yakni penyelesaian sengketa secara damai dan penyelesaian sengketa dengan paksaan atau kekerasan. Berikut masingmasing cara penyelesaian sengketa itu ;

1. Penyelesaian Sengketa Secara Damai Penyelesaian sengketa secara damai dapat dilakukan melalui beberapa cara, yakni Mediasi, penyelesaian sengketa di bawah perlindungan Perserikatan Bangsa-bangsa, arbitrasi dan peradilan. masing-masing cara penyelesaian sengketa itu adalah sebagai berikut :

a. Mediasi

Mediasi adalah penyelesaian sengketa melalui usaha penye-

17) Mahfud dan Rosmawati, Hukum Internasional, Unsyiah Perss, Darusallam, Banda Aceh, 2015, hlm 123 
suaian pendapat antara pihakpihak yang bersengketa secara bersahabat. Mediasi dapat dilakukan oleh pihak-pihak yang bersengketa dengan mengadakan negosiasi, dengan jasa baik atau mediasi, dengan konsiliasi dan dengan panitia penyelidikan.

b. Negosiasi

Negosiasi adalah perundingan antar pihak-pihak yang bersengketa. Negosiasi itu merupakan sarana untuk menetapkan penyesuaian kebijakan atau sikap tentang masalah yang disengketakan.

2. Penyelesaian Sengketa di Bawah Pengawasan Perserikatan Bangsabangsa

Peranan Perserikatan Bangsa-bangsa dalam penyelesaian sengketa secara damai dapat dilakukan melalui penyelesaian secara politik atau penyelesaian secara hukum. Peryelesaian secara politik dilakukan oleh Majelis Umum dan Dewan Keamanan Perserikatan Bangsa-bangsa sedang pernyelesaian secara hukum dilakukan oleh Mahkamah Internasional. Peranan Majelis Umum Perserikatan Bangsa-bangsa dalam menyelesaikan sengketa secara damai dilakukan dengan memberikan rekomendasikan tindakan-tindakan yang perlu untuk penyelesaian secara damai keadaan yang mengganggu kesejahteraan umum atau persahabatan antar negara. Wewenang Majelis Umum dapat dilakukan kecuali bila Dewan Keamanan Perserikatan Bangsabangsa sedang menangani sengketa itu. $^{18)}$

Ketentuan tentang pola penyelesaian konflik bersenjata tersebut diatas juga digunakan dalam metode pendekatan resolusi konflik. Hal tersebut beralasan karena konflik bersenjata akan melahirkan persoalan-persoalan kemanusiaan. Oleh karenanya upaya-upaya untuk meredam agar tidak munculnya konflik bersenjata baik itu konflik bersenjata antar negara maupun negara dengan kelompok entitas internasional seperti pemberontak. Dalam metode identifikasi resolusi konflik pertikaian bersenjata penyebab terjadinya konflik bersenjata sangat dipengaruhi oleh tiga kondisi diantaranya :

1. Kondisi di mana konflik mungkin terjadi, yang meyangkut penyebab pasti konflik.

2. Bagaimana potensi konflik itu muncul, serta

3. Bagaimana cara untuk mengontrol situasi supaya konflik tidak berkembang. ${ }^{19)}$

18) I bid

19) http://indira-a-fisip10.web.unair.ac.id/artikel_detail-59901Resolusi\%20Konflik\%20GlobalPencegahan\%20dan\%20Penyelesaian\%20Kekeras an\%20Konflik.html 
Disisi lain upaya untuk mencegah konflik bersenjata bersenjata dapat ditempuh melalui dua mekanisme pencegahan konflik diantaranya :

1. Light prevention, merupakan upaya untuk mencegah situasi kekerasan mengarah pada konflik bersenjata sehingga ia tidak berusaha untuk menyelidik lebih dalam pada sumber dan akar konflik. Contohnya adalah usaha-usaha mediasi dan intervensi diplomatik

2. Deep prevention merupakan upaya untuk menemukan akar konflik dengan menekankan hubungan dan kepentingan atas konflik tersebut dalam tatanan kapasitas domestik, regional, dan internasional untk mengelola konflik, yang melibatkan seluruh elemen konflik dan bertujuan untuk mengurangi kemungkinan timbulnya konflik. ${ }^{20)}$

Untuk mencegah konflik atau perang sebelumnya harus diidentifikasi terlebih dahulu tipe konflik dan lokasi potensi-potensi konflik. Dan pencegahan bersifat relatif, bergantung pada aktornya baik konflik interstate wars maupun non-interstate war. Interstate war menitikberatkan pada perang yang dilakukan antara negara-negara dengan kapasitas power yang besar. Misalnya adalah LBB dan Perjanjian Versailles bertindak sebagai alat preventif perang yang terjadi pada Perang Dunia I dan Perang Dunia II.
Sementara non-interstate war mengarah pada konflik-konflik yang meliputi konflik etnis karena adanya stratifikasi sosial, polarisasi masyarakat, inappropriate systemic, regional diasporas, dan sebagainya.

Berdasarkan uraian diatas pola pendekatan pada kontek resolusi konflik lebih terarah pada upaya dari awal pada tahap mencegah munculnya koflik bersenjata. Upaya tersebut bisa dilakukan dengan upaya mediasi dan diplomasi politik dengan melibatkan berbagai pihak yang dianggap bisa menjadi aktor-aktor perdamaian. Contoh konkrit tersebut dapat dilihat dalam upaya diplomasi untuk meredam potensi konflik bersenjata yang muncul antara Cina dan sejumlah negara Asia Tenggara menyangkut dengan klaim tumpang tindih atas sejumlah kepulauan yang ada di laut Cina Selatan.

Upaya tersebut dilakukan dengan melibat organisasi kawasan ASEAN sebagai payung perdamaian guna meredam dan mencegah potensi konflik bersenjata akibat aksi klaim anatara Ciana dan hampir seluruh negara ASEAN atas sejumlah wilayah kepulauan Spatly dan Paracel. Negara-negara ASEAN menyepakati Code of Condact $(\mathrm{CoC})$ atau kode berprilaku dengan Cina yang dipandang semakin agresif merebut dan mengklaim sebagai bagian intergeral Cina dengan membangun sejumlah pulau buatan 
yang ada di wilayah yang dipersengketakan tersebut. $^{21)}$

\section{Konflik Bersenjata dan Upaya Pencegahan Konflik Bersenjata dalam Konteks Hukum Internasional Hukum Humaniter}

Atas dasar pengalaman sejarah dan tantangan-tantangan yang dihadapi bangsabangsa di dunia dalam usaha menciptakan stabilitas dan suasana hidup bertetangga baik di kawasannya, telah sepakat untuk mencari tema-tema pokok perdamaian, yaitu menciptakan dunia sebagai kawasan damai, bebas dan netral dari pertentangan negaranegara besar. Negara-negara tersebut menyetujui pembentukan suatu mekanisme untuk menyelesaikan perselisihan antara negara anggota secara damai. Pembentukan LBB dan PBB merupakan salah satu tujuannya untuk mencapai tujuan tersebut. Jika Perserikatan Bangsa-Bangsa dibentuk pada waktu berlangsungnya Perang Dunia II, Liga Bangsa-Bangsa diciptakan justru setelah berakhirnya Perang Dunia I, hal ini dapat dilihat dalam pernyataan berikut :

"... whereas the Covenant of the League was formulated after hostilities were ended, the main features of the United Nations were devised while war was still in progress."

21) Edisi Koleksi Angkasa, Kekuatan Laut di Asia Fasifik, ketika Perang Dingin Tak Berakhir Dengan Perdamaian, Agustus 2013, hlm 20.
"The collapse of the League of Nations led almost automatically to consideration of the nature of its replacement, and similar failure by the United Nations might be expected to produce the same reaction. A tense of history provides the basis for the understanding that international organization has become a necessary part of the system for dealing with international problems and that to organize or not to organize is no longer an open question for statesman or a useful one for students of international relation.", 22$)$

Setelah berakhirnya perang dunia yang menghancurkan, PBB berdiri pada tahun 1945 untuk menstabilkan hubungan internasional dan memberikan dasar yang lebih kuat bagi perdamaian. Setelah saat itu, Organisasi dunia tersebut telah menjadi saksi maupun pendorong dalam peralihan yang hebat dalam hubungan global. Dari reruntuhan Perang Dunia II, melalui tahuntahun yang diselubungi persaingan antara blok-blok negara besar, ancaman perang nuklir, biologi, kimia dan konflik regional yang kelihatannya tak ada akhirnya, PBB telah berkembang menjadi satu organisasi dimana upaya bersama untuk mencapai stabilitas, dengan perdamaian sebagai dasarnya, telah menjadi kepedulian yang utama. Pembahasan mengenai prinsipprinsip peningkatan perdamaiann terutama

\footnotetext{
22) Sumaryo Suryokusumo, Hukum Organisasi Internasional, Universitas Indonesia Press, Jakarta, 1990, hlm 7-8.
} 
dilaksanakan oleh Majelis Umum berdasarkan Pasal 11 ayat 1 Piagam, yang menegaskan bahwa $:^{23)}$

"The General Assembly may consider the general principles of co-operation in the maintenance of international peace and security, including the principles governing disarmament and the regulation of armaments, and may make recommendations with regard to such principles to the Members or to the Security Council or to both". ${ }^{24)}$

Dalam piagam Perserikatan BangsaBangsa dengan jelas disebutkan bahwa tujuan dari organisasi ini adalah untuk memelihara perdamian dan keamanan internasional, hal ini sebagaimana tertuang dalam Pasal 1 dari Piagam $\mathrm{PBB},{ }^{25)}$ serta

23) Pengetahuan Dasar Mengenai Perserikatan Bangsa-Bangsa, Kantor Penerangan Perserikatan Bangsa-Bangsa, Jakarta, 1998, hlm 33.

24) Bunyi Pasal 11 ayat (1) Piagam PBB.

25) Adapun bunyi dari Pasal 1 Piagam PBB : The Purposes of the United Nations are:

1. To maintain international peace and security, and to that end: to take effective collective measures for the prevention and removal of threats to the peace, and for the suppression of acts of aggression or other breaches to the peace, and to bring about by peaceful means, and in conformity with the principles of justice and international law, adjustment or settlement of intenational disputes or situations which might lead to a breach of the peace;

2. To develop friendly relations among nations based on respect for the principle of equal rights and self-determination of peoples, and to take other appropriate measures to strengthen universal peace;

3. To achieve international co-operation in solving international problems of an economic, social, cultural, or humanitarian character, and in promoting and encouraging respect for human rights and for fundamental freedoms for all without distinction as to race, sex, language, or religion; and. berupaya untuk menyelesaikan sengketasengketa antara negara dengan menggunakan jalan damai. Dalam Piagam juga ditegaskan larangan penggunaan kekerasan terhadap integritas wilayah atau kemerdekaan politik suatu negara (Pasal 2 Ayat 4 Piagam PBB). ${ }^{26)}$ Namun demikian dalam kenyataannya, setelah berakhirnya perang dunia II, perang masih banyak terjadi di berbagai belahan dunia. Masih banyak negara-negara yang menyelesaikan konflik diantara mereka dengan menggunakan kekuatan militer, baik dalam skala besar maupun kecil.

Akhir dari perang dingin pun juga tidak membawa suatu perdamaian, atau mendekati suatu harapan untuk suatu pesan dunia baru yang belum terealisasikan. Sebagaimana laporan Seketaris Jenderal PBB tahun 1995, sampai saat ini (akhir dari perang dingin), dimana terdapat suatu kepercayaan yang tersebar secara luas bahwa ketika tidak ada lagi kekuatan-kekuatan besar yang saling bersaing, maka konflik-konflik regional yang terjadi di berbagai belahan dunia yang berlainan ini dengan sendirinya akan berhenti. $^{27)}$ Oleh karena itu banyak pihak sependapat, bahwa walau tak setuju akan

4. To be a centre for harmonizing the actions of nations in the attainment of these common ends.

26) Adapun bunyi dari Pasal 2 ayat (4) Piagam PBB :

All Members shall refrain in their international relations from the threat or use of force against the territorial integrity or political independence of any state, or in any other manner inconsistent with the Purposes of the United Nations.

27) Gray, Christine, International Law and The Use of Force, OXFORD University Press, New York, 2000, hlm 1. 
adanya perang, dunia harus memiliki hukum perang.

Bagaimanapun perangkat hukum tersebut harus ada, karena memang hanya dengan instrumen inilah hak-hak warga sipil dari negara yang sedang bertikai bisa dijaga dan dihormati. Orang-orang dan properti yang tak kaitannya dengan perang harus dilindungi dari perusakan yang tak perlu. Demikian bunyi salah satu baris legalisasi secara internasional terhadap intervensi yang dapat dilakukan oleh PBB. PBB melalui Dewan Keamanannya yang hanya menangani penyelesaian dua macam sengketa, yakni :

a). Sengketa yang dapat membahayakan perdamaian dan kemanan internasional dan

b) Peristiwa ancaman perdamaian, pelanggaran perdamaian atau perbuatan agresi.

Dalam menyelesaikan sengketa yang dapat membahayakan perdamaian dan keamanan internasional, Dewan Keamanan dapat minta kepada pihakpihak yang bersengketa untuk menyelesaikan sengketa melalui negosiasi, mediasi, konsiliasi, penyelidikan, arbitrasi atau peradilan. Dewan Keamanan dapat setiap saat merekomendasikan cara yang tepat untuk menyelesaikan sengketa itu. Dalam peristiwa ancaman perdamaian, pelanggaran perdamaian atau perbuatan agresi, Dewan Keamanan berwenang merekomendasikan atau memutuskan saranan yang diperlukan untuk mempertahankan atau mengembalikan perdamaian dan keamanan internasional. Dewan keamanan juga dapat minta kepada pihak-pihak yang bersangkutan untuk memenuhi tindakan yang ditetapkan.

Dalam kontek normatif hukum humaniter upaya penegakan hukumnya terpatri pada situasi perang yang sedang berlangsung. Upaya perdamaian yang dianggap sebagai diplomasi yang punya misi politik justru sering digunakan ketika perang yang sedang berlangsung tersebut telah melenceng dari prinsip Ius in Bello dan Ius ad Bellum. Pelangaran dari prinsipprinsip hukum perang inilah yang kemudian memunculkan intervesi asing dalam konflik bersenjata yang sedang berlangsung itu sendiri. Intervensi kemanusiaan juga dapat diartikan sebagai intervensi bersenjata yang dilakukan oleh suatu negara dengan pertimbangan kemanusiaan. Intervensi ini bukan bertujuan untuk mengganti kedaulatan suatu negara tetapi menyelamatkan para korban perlakuan brutal atau kejam dan tidak manusiawi yang dialami di suatu negara.

\section{Kesimpulan}

Dewasa ini masyarakat internasional akan lebih dapat menerima suatu intervensi kemanusiaan yang dilakukan dengan 
otorisasi dari Dewan Keamanan PBB. dari intervensi ini. Ada tiga alasan pokok Penggunaan kekerasan untuk tujuan penolakan terhadap keberadaan intervensi humaniter tidak sesuai dengan tujuan Piagam kemanusiaan, yaitu:

PBB kecuali setelah mendapat otorisasi dari

Dewan Keamanan PBB. ${ }^{28)}$ Sebaliknya, intervensi kemanusiaan yang dilakukan oleh suatu negara tanpa otorisasi Dewan Keamanan PBB, akan diragukan legalitasnya dan cenderung mendapat penolakan dan kecaman dari masyarakat internasional. Contohnya adalah intervensi militer yang dilakukan NATO di Kosovo pada Tahun 1999. Intervensi ini oleh sebagian besar sarjana dipandang sebagai tindakan unilateral dari NATO tanpa ada otorisasi dari Dewan Keamanan PBB. ${ }^{29)}$

Melihat keabsahannya yang melibatkan penggunaan kekuatan bersenjata, bukan suatu kejutan jika keberadaan intervensi kemanusiaan menjadi hal yang konterversial dan cenderung mendapat penolakan. Hal ini diperkuat dengan tidak jelasnya dasar hukum

28) Boer Mauna, Hukum Internasional: Pengertian, Peranan dan Fungsi Dalam Era Dinamika Global, Edisi ke-2, Bandung: PT.Alumni, 2003, hlm 652.

29) Lihat pernyataan yang dikemukanan oleh salah satu hakim dari "The Flouse of Lords" yang menangani kasus tersebut patut diperhatikan : “... on the same day that we delivered our judgment [on Pinochet Case], NATO forces began to bomb the sovereign state of Serbia in an attempt to stop the attrocities its government was committing against its own citizens in Kosovo. Two events on the a single day showed how far we had come from the classical doctrines of international law as we had learned them fifty years ago. No longer is international law a matter which concerns sovereign States alone. It marches with human rights law to protect individuals from State action"., Jawahir Thontowi dan Pranto Iskadar, Hukum Internasional Kontemporer, Refika Aditama, Bandung, 2006, hlm 1
1. Piagam PBB dan korpus hukum internasional modern secara khusus tidak berisikan hak intervensi kemanusiaan.

2. Praktik negara-negara terutama sejak tahun 1945 menunjukan bahwa sangat sedikit kasus-kasus intervensi kemanusiaan yang benar-benar dilandasi pertimbangan kemanusiaan.

3. Atas dasar keberhati-hatian yaitu terbuka kemungkinan terhadap penyalahgunaan hak tersebut, sehingga menyebabkan suatu negara tidak tertarik untuk mengijinkan intervensi kemanusiaan. ${ }^{30)}$

Atas dasar pertimbangan itulah yang menyebabkan pergeseran para digma dari intervensi kemanusiaan humanitarian intervention ke responsibility to protect ( $\mathrm{R}$ to P). Karena dengan adanya tindakan intervensi kemanusiaan, masyarakat internasional berpendapat bahwa pelaksanaan tindakan tersebut melemahkan kedaulatan negara, berpotensi merusak aturan yang ada di dalam piagam Perserikatan BangsaBangsa (PBB), mengancam pemerintahan yang sah dalam negara yang diintervensi, dan mengancam stabilitas internasional. Dengan demikian munculnya norma baru yaitu $\mathrm{R}$ to $\mathrm{P}$ dengan cara yang lebih mendukung dan dapat di terima oleh banyak negara.

Ketentuan PBB sebagai salah satu organisasi besar dunia yang memiliki kekuasaan dan tanggung jawab yang dituntut untuk mengambil tindakan-tindakan tertentu

30) Boer Mauna,Op.Cit, hlm.651 
atas pelangaran prinsip-prinsip hukum perang dan HAM. Termasuk tanggung jawab baik untuk menfasilitasi proses perdamaian, mencegah semakin memburuknya eskalasi konflik bersenjata hingga mencegah terjadinya konflik bersenjata. Ketentuan tersebut sebagaimana diatur dalam pasal 41 dan 42 dalam Piagam PBB yang menyatakan .31)

Pasal 41:

The Security Council may decide what measures not involving the use of armed force are to be employed to give effect to its decisions, and it may call upon the Members of the United Nations to apply such measures. These may include complete or partial interruption of economic relations and of rail, sea, air, postal, telegraphic, radio, and other means of communication, and the severance of diplomatic relations.

Pasal 42:

"Should the Security Council consider that measures provided for in Article 41 would be inadequate or have proved to be inadequate, it may take such action by air, sea, or land forces as may be necessary to maintain or restore international peace and security. Such action may include demonstrations, blockade, and other operations by air, sea, or land forces of Members of the United Nations.

Kedua Pasal Piagam PBB tersebut memberikan kesan bahwa peran dan fungsi yang dijalankan oleh PBB untuk mengambil tindakan kolektif terhadap upaya pencegahan konflik bersenjata maupun eskalasi dari kekejaman atas setiap pelangaran dari norma hukum perang itu sendiri. langkah pencengahan maupun meminimalisasi dampak dari konflik bersenjata tersebut dapat dilihat dalam Resolusi Majelis Umum PBB No. A/60/I tanggal 24 Oktober 2005, khususnya Paragraf 139 yang menyatakan :

The international community, through the United Nations, also has the responsibility to use appropriate diplomatic, humanitarian and other peaceful means, in accordance with Chapters VI and VIII of the Charter, to help to protect populations from genocide, war crimes, ethnic cleansing and crimes against humanity. In this context, we are prepared to take collective action, in a timely and decisive manner, through the Security Council, in accordance with the Charter, including Chapter VII, on a case-by-case basis and in cooperation with relevant regional organizations as appropriate, should peaceful means be inadequate andnational authorities are manifestly failing to protect their populations from genocide, war crimes, ethnic cleansing and crimes against humanity. We stress the need for the General Assembly to continue consideration of the responsibility to protect populations from genocide, war crimes, ethnic cleansing and crimes against humanity and its implications, bearing in mind the principles of the Charter and international law. We also intend to commit ourselves, as necessary and appropriate, to helping States build capacity to protect their populations from genocide, war crimes, ethnic cleansing and crimes against humanity and to assisting those which

\footnotetext{
${ }^{31)}$ Lihat Pasal 41 dan 42 Piagam PBB.
} 
are under stress before crises and conflicts break out. ${ }^{132)}$

Resolusi PBB tersebut dalam konteks hukum humaniter merupakan cikal bakal dari lahirnya dokrin hukum internasional berupa $\mathrm{R}$ toP. $\mathrm{R}$ to $\mathrm{P}$ adalah suatu prinsip yang berusaha menjamin agar komunitas internasional tidak akan gagal lagi untuk bertindak ketika pembunuhan massal dan kejahatan kemanusiaan lainnya terjadi dalam suatu konflik bersenjata. Suatu sistem yang sekarang telah diakui oleh komunitas internasional barawal dari Resolusi Majelis Umum PBB nomor A/RES/60/1 pada tanggal 24 Oktober 2005 hasil Konferensi Tingkat Tinggi dunia (world summit outcome).

Dalam perkembanganya prinsip $\mathrm{R}$ to $\mathrm{P}$ juga masih terdapat perbedaan pendapat, apakah $\mathrm{R}$ to $\mathrm{P}$ itu merupakan ketentuan hukum atau bukan. Hakikatnya sampai saat ini ' $\mathrm{R}$ to $\mathrm{P}$ ' bukanlah suatu rumusan hukum, tapi merupakan suatu 'concept', 'principle', 'evolvingtrend', 'strong political commitment', 'emerging norm', atau suatu 'obligation with legal significance. ${ }^{2}$ 33) Faktanya bahwa saat ini ' $\mathrm{R}$ to $\mathrm{P}^{\prime}$ telah disepakati dan diterima oleh mayoritas negara-negara di dunia yang menjadi anggota PBB melalui Resolusi Majelis Umum. Dasar yang sangat utama dapat pelaksanaan Basic

32) United nations, Resolution adopted by the General Assembly..No.A/res/60/1.Oktober 2005.

33) Conference on the United Nations of the Next Decade, Actualizing the Responsibility to Protect, Stanley Foundation, Portugal, 20 - 25 June 2008, hlm 2.
Principles The Responsibility To Protect yaitu:

a. State sovereignty implies responsibility, and the primary responsibility for the protectionof its people lies with the state itself (kedaulatan negara termasuk tanggung jawab, dan tanggung jawab utama untuk melindungi rakyatnya yang berada pada negara itu sendiri).

b. Where a populations is suffering serious harm, as a result of international war, insurgency, repression or state failure, and the state in question is unwilling or unable to halt or avert it, the principle of non-intervention yields to the international responsibility to protect (Dimana populasi yang menderita bahaya serius, sebagai akibat dari perang internasional, pemberontakan, penindasan atau negara gagal, dan negara yang dimaksud adalah mau atau tidak mampu menghentikan atau mencegah itu, prinsip non-intervensi menjadi tanggung jawab untuk melindungi internasional). ${ }^{34)}$

Dari perspektif hukum, konsep 'R to $\mathrm{P}^{\prime}$ sebagaimana diadopsi dalam Resolusi Majelis Umum PBB No.A/60/I khususnya Paragraf 138 dan 139, bersifat rekomendatif, artinya tidak mempunyai kekuatan hukum mengikat meskipun tetap memiliki muatan politik dan moral yang cukup penting dalam menciptakan norma internasional yang baru. Hal ini bukan berarti bahwa dengan alasan $\mathrm{R}$ to $\mathrm{P}$ sebagaimana diatur dalam Paragraf tersebut masyarakat internasional dapat dengan mudahnya melakukan intervensi militer, karena harus lebih dulu dilakulan upaya-upaya pencegahan, penghentian dan

34) ICISS, The Responsibility to Protect, Report of the International Commission on Intervention and State Souvereignty, December 2001 hlm XI. 
penyelesaian masalahnya secara damai intervensi militer harus menjadi pilihan terakhir dengan justifikasi dan legitimasi PBB dengan memperhatikan beberapa kriteria, yaitu:

1. Tindakan tersebut harus memiliki dasar pembenaran yang adil (just cause) karena telah terjadi kekejaman massal.

2. Tujuan yang benar (right intension) berupa usaha untuk menghentikan penderitaan manusia.

3. Merupakan langkah terakhir (final resort) karena semua segala langkah damai baik yang bersifat diplomasi maupun non militer ternyata gagal.

4. Didasarkan pada keabsahan kewenangan (legitimate authority) dengan mandat Dewan Keamanan PBB.

5. Menggunakan sarana yang proporsional (propotional means), artinya tidak berlebihan baik dari sisi alat maupun tujuan sesuai dengan hukum humaniter.

6. Intervensi militer itu dilakukan dengan jaminan sukses untuk menghentikan kekejaman dan penderitaan massal (reasonable prospect). ${ }^{35)}$

Disisi lain dalam pelaksanaannya prinsip ' $\mathrm{R}$ to $\mathrm{P}^{\prime}$ haruslah meliputi 3 (tiga)

jenis tanggung jawab yang meliputi yaitu:

a. The responsibility to prevent: to address both the root causes and direct causes of internal conflict and other man-made crises putting populations at risk(Tanggung jawab untuk mencegah: untuk mengatasi kedua akar penyebab dan penyebab langsung dari konflik internal dan krisis buatan lainnya menempatkan populasi yang berisiko).

35) Rahayu.Op.Cit. hlm 135 Rahayu.Eksistensi Prinsip 'Responsibility To Protect' Dalam Hukum Internasional ( jilid 41 no. 1).Fakultas Hukum Universitas Diponegoro Semarang , 2012, hlm 135-136 b. The responsibility to react: to respond to situations of compelling human need with appropriate measures, which may include coercive measures like sanctions and international prosecution, and in extreme cases military intervention(Tanggung jawab untuk bereaksi: untuk menanggapi situasi kebutuhan manusia menarik dengan langkah yang tepat, yang dapat mencakup langkah-langkah paksaan seperti sanksi dan penuntutan internasional, dan dalam kasus yang ekstrim intervensi militer).

c. The responsibility to rebuild: to provide, particularly after a military intervention, full assistance with recovery, reconstruction and reconciliation, addressing the causes of the harm the intervention was designed to halt or avert(Tanggung jawab untuk membangun kembali: untuk menyediakan, terutama setelah intervensi militer, bantuan penuh dengan pemulihan, rekonstruksi dan rekonsiliasi, mengatasi penyebab kerusakan intervensi dirancang untuk menghentikan atau mencegah). ${ }^{36)}$

Harapannya adalah dengan menerapkan tiga jenis tanggung jawab $\mathrm{R}$ to $\mathrm{P}$ tersebut, komunitas internasional akan siap merespon setiap tahapan dari eskalasi konflik bersenjata yang terjadi dalam suatu negara baik itu konflik bersenjata internasional, nasional maupun internasionalisasi dari konflik bersenjata itu sendiri. Komitmen Komunitas Internasional terhadap Responsibility to Protect adalah Pada tahun 2005, PBB menggelar Konferensi Tingkat Tinggi (KTT) Dunia yang menghadirkan sejumlah pemimpin dari berbagai negara di dunia. Salah satu capaian penting dari KTT

36) Ibid. 
Dunia tersebut adalah kesepakatan bulat di antara para pemimpin dunia bahwa semua negara memiliki tanggung jawab untuk melindungi rakyatnya dari pemusnahan massal, kejahatan perang, kejahatan terhadap kemanusiaan dan pembersihan etnis.Mereka juga sepakat untuk siap mengambil tindakan kolektif ketika suatu negara gagal melindungi rakyatnya dari empat jenis kejahatan tersebut.

Selain melalui mekanisme PBB upaya untuk terus menerus komunitas internasional mencegah munculnya konflik bersenjata juga dengan melibatkan sejumlah aktor-aktor lain yang bisa dianggap sebagai mitra perdamaian. Salah satunya dengan melibatkan kelompok-kelompok tertentu yang dianggap sebagai bisa menjadi pihak yang akan memutuskan mata rantai konflik bersenjata itu sendiri. Salah satunya melalui mekanisme Kimberley Proses.

Kimberley Proses melalui Skema Sertifikasi Proses Kimberley/Kimberley Process Certification Scheme (KPCS) yang diperkenalkan oleh Resolusi Majelis Umum Perserikatan Bangsa-Bangsa 55/56 tahun 2000, merupakan salah satu upaya untuk memutuskan mata rantai pembiayaan dari konflik bersenjata itu sendiri. KPCS adalah proses yang ditetapkan untuk menyertifikasi asal usul intan kasar dari sumber-sumber yang bebas dari konflik yang didanai oleh produksi intan. Proses ini dibentuk tahun 2003 untuk mencegah hasil penjualan intan mengalir ke gerakan-gerakan pemberontak. Skema ini dibentuk untuk menjamin konsumen bahwa dengan membeli intan mereka tidak mendanai perang dan pelecehan HAM

KPCS menerapkan persyaratan ketat bagi anggotanya agar mengawasi dan mencegah berlian bermasalah memasuki pasar resmi. Untuk itu para anggota KPCS (termasuk Indonesia yang menjadi anggota sejak 1 Agustus 2005) diminta untuk melaksanakan kontrol internal dan semua penjualan berlian yang belum diolah harus disertai sertifikat mengenai asal usul berlian. ${ }^{37)}$ Hal tersebut sebagaimana dinyatakan dalam Section I Definitions apa itu berlian konflik yang menyatakan :

Conflict Diamonds means rough diamonds used by rebel movements or their allies to finance conflict aimed at undermining legitimate governments, as described in relevant United Nations Security Council (UNSC) resolutions insofar as they remain in effect, or in other similar UNSC resolutions which may be adopted in the future, and as understood and recognised in United Nations General Assembly (UNGA) Resolution 55/56, or in other similar UNGA resolutions which may be adopted in future, ${ }^{38)}$

\footnotetext{
37) Sumber

http://arishu.blogspot.co.id/2007/12/mengenal-

kimberly-proses.html

38) Lihat Section I Definitions Kimberley Process Certification Scheme (KPCS) yang diperkenalkan oleh Resolusi Majelis Umum Perserikatan BangsaBangsa 55/56 tahun 2000.
} 
Sejauh ini mekanisme di dalam KPCS terbukti bisa mengakhiri mimpi buruk di kawasan konflik berlian dan kedepannya hal tersebut diharapkan dapat terus berlanjut dengan baik. Contoh kasus tersebut dapat dilhat dalam konflik bersenjata yang terjadi Liberia. Liberia porak-poranda setelah 14 tahun perang saudara. Selama perang saudara 1989-2003, pihak-pihak yang bertikai menggali sumber daya berlian dan hasil penjualannya digunakan untuk mendanai pembelian senjata. Situasi tersebut membuat PBB menjatuhkan sanksi pada Liberia melalui paragraf 6 Resolusi 1521 tahun 2003 tentang embargo atas berlian mentah Liberia. Resolusi tersebut dianggap efektif untuk memutus mata rantai konflik yang sedang mendera Liberia saat itu.

Hal tersebut daopat dilihat dari keputusan Dewan Keamanan PBB mencabut Resolusi 1521 pada 2003. Liberia dinilai telah membuat kemajuan dalam mengeluarkan sertifikat asal berlian mentahnya. DK PBB, yang memiliki 15 anggota, dengan suara bulat mensahkan rangancan resolusi AS yang membatalkan resolusi 2003 mengenai embargo atas berlian mentah Liberia. DK PBB menyatakan akan mengkaji tindakannya dalam 90 hari, berdasarkan penilaian yang akan diterimanya dari Proses Kimberley mengenai penampilan Liberia. Apa yang disebut "berlian darah" dan batu mulia lain dieksport secara tidak sah untuk mendanai pembelian senjata, praktek yang menyulut perang saudara di Liberia, Sierra Leone dan Republik Demokratik Kongo. Berdasarkan Proses Kimberley, berlian mentah disimpan di wadah anti-pecah dan diharuskan memperoleh sertifikat bebaskonflik dan anti-pemalsuan dengan pemberian angka serial unik setiap kali berlian itu melintasi satu perbatasan internasional. Pada Desember, DK PBB memperbarui sanksi terhadap Liberia dengan melarang perdagangan berlian dan senjata serta ditujukan kepada perorangan di Liberia. $^{39)}$

\section{DAFTAR PUSTAKA}

\section{Buku dan Jurnal}

Arlina Permana Sari dkk, Pengantar Hukum Humaniter, ICRC, Jakarta, 1999.

Aust, Anthony, Handbook of International Law, Published in The United State by Cambrige University Press, New York, 2005.

Boer Mauna, Hukum Internasional: Pengertian, Peranan dan Fungsi Dalam Era Dinamika Global, Edisi ke-2, Bandung: PT.Alumni, 2003.

E. Koswara, Agresi Manusia, PT Eresco, Bandung, 1988.

Evans, Malcom D, International Law, Published in The United State by Oxford University Press Inc, New York, 2003.

H.A. Masyur Effendi, Hukum Humaniter Internasional dan Pokok-Pokok HANKAMRATA, Usaha Nasional, Surabaya, 1994.

Lachs, Manfred, Responsibility For The Development of Humanitarian Law, and Cristopher Swinarski (Ed), Studies and Essay on

39) http://www.antaranews.com/berita/60782/pbbcabut-embargo-berlian-liberia 
International Humanitarian Law and Red Cross Principles, Martinus Nijhoff Publishers, Laiden, 1984.

Majid Khadduri, War and Peace in The Law of Islam (Perang dan Damai dalam Hukum Islam), Tarawang Press, Jakarta, 2002.

Mahfud dan Rosmawati, Hukum Internasional, Unsyiah Perss, Darusallam, Banda Aceh, 2015.

Mochtar Kusumaatmadja, KonvensiKonvensi Palang Merah 1949, PT Alumni, Bandung, 2002.

Rahayu.Eksistensi Prinsip 'Responsibility To Protect' Dalam Hukum Internasional ( jilid 41 no. 1).Fakultas Hukum Universitas Diponegoro Semarang, 2012.

Romli Atmasasmita, Pengantar Hukum Pidana Internasional, Refika Aditama, Bandung, 2000.

Sumaryo Suryokusumo, Hukum Organisasi Internasional, Universitas Indonesia Press, Jakarta, 1990.

T. May Rudy, Hukum Internasional 2, Refika Aditama, Bandung, 2001.

\section{Konvensi dan Undang-undang}

Conference on the United Nations of the Next Decade, Actualizing the Responsibility to Protect, Stanley Foundation, Portugal, 20 - 25 June 2008.

ICISS, The Responsibility to Protect, Report of the International Commission on Intervention and State Souvereignty, December 2001.

Kimberley Process Certification Scheme (KPCS) yang diperkenalkan oleh Resolusi Majelis Umum Perserikatan Bangsa-Bangsa 55/56 tahun 2000.

Piagam PBB 1945
United nations, Resolution adopted by the General Assembly..No.A /res/60/1.Oktober 2005.

\section{Internet dan Sumber Lain}

Buletin ICRC, ICRC Dalam Kilasan, Maret 2001.

$\begin{array}{lr}\text { Hukum } & \text { Humaniter } \\ \text { Internasional } & \text { (Menjawab } \\ \text { Pertanyaan-pertanyaan Anda), } \\ \text { Febuari 2004. }\end{array}$

Edisi Koleksi Angkasa, Kekuatan Laut di Asia Fasifik, ketika Perang Dingin Tak Berakhir Dengan Perdamaian, Agustus 2013.

----------, Pistol, Rifles, and Machine Gun, April 2006.

http://www.antaranews.com/berita/60782/ pbb-cabut-embargo-berlianliberia

http://arishu.blogspot.co.id/2007/12/meng enal-kimberly-proses.html

http://indira-a--

fisip10.web.unair.ac.id/artikel_de tail-59901-

Resolusi\%20Konflik\%20GlobalPencegahan $\% 20$ dan $\% 20$ Penyeles aian\%20Kekerasan\%20Konflik.h tml

Pengetahuan Dasar Mengenai Perserikatan Bangsa-Bangsa, Kantor Penerangan Perserikatan Bangsa-Bangsa, Jakarta, 1998. 